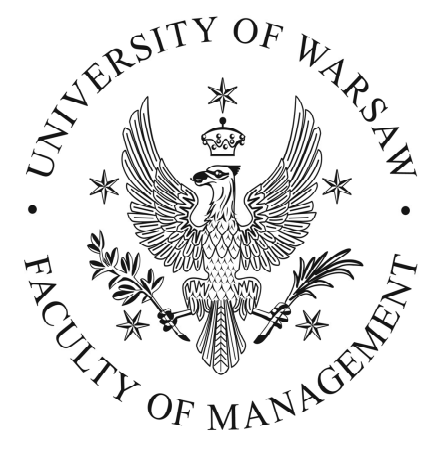

UW Faculty of Management

Working Paper Series

No 3 / October 2013

\title{
The empirical analysis of dynamic relationship between financial intermediary connections and market return volatility
}

\author{
Renata Karkowska \\ University of Warsaw, Faculty of Management \\ Poland \\ rkarkowska@wz.uw.edu.pl
}

JEL classification: G1, G11, G10, M21

Keywords: financial market, hedge fund, market instability, volatility 
UW FM Working Paper Series are written by researchers employed at the Faculty of Management of UW and by other economists, and are published by the Faculty.

DISCLAIMER: An objective of the series is to get the research results out quickly, even if their presentations are not fully polished. The findings, interpretations, and conclusions expressed in this Working Paper are those of their author(s) and do not necessarily the views of the Faculty of Management of UW.

(C) UW Faculty of Management 2013. All rights reserved. The papers are written by the authors and should be cited accordingly.

Publisher: University of Warsaw, Faculty of Management Press

Address:

Str.: Szturmowa 1/3; 02-678 Warsaw, Poland

Telephone: +48225534164

Fax: +48 225534001

This paper can be downloaded without charge from: http://www.wz.uw.edu.pl/serwisy, witryna, 1,dzial,326.html Information on all of the papers published in the UW Faculty of Management Working Paper Series can be found on Faculty of Management Website at: http://www.wz.uw.edu.pl/serwisy,witryna, 1,dzial,326.html

\section{ISSN 2300-4371 (ONLINE)}




\title{
The empirical analysis of dynamic relationship between financial intermediary connections and market return volatility
}

\author{
Renata Karkowska ${ }^{1}$ \\ University of Warsaw, Faculty of Management \\ Poland \\ rkarkowska@wz.uw.edu.pl
}

\begin{abstract}
Article aims to demonstrate the significant impact of dynamics of the relationship between financial intermediaries on the level of market volatility. Particularly important are the growing share of the links between hedge funds and other financial institutions. In order to demonstrate the dynamic test was presented Granger causality, which allows the statistical analysis of cause and effect relationships in the risk spread in the financial system. Using multiple regression analysis study was calculated the impact of the hedge fund market development (measured in assets, leverage, the price volatility in various financial markets). Due to data availability study has been limited to 10-year period of analysis (2001-2011). The results show a significant correlation between the volatility in the stock market, bonds and CDS, and the activities of hedge funds on financial markets.
\end{abstract}

JEL classification: G1, G11, G10, M21

Keywords: financial market, hedge fund, market instability, volatility

\footnotetext{
${ }^{1}$ Corresponding author : PhD Renata Karkowska, University of Warsaw, Faculty of Management, Institute of Financial Systems of Economy, Str. Szturmowa 1/3, post code 02-678 Warsaw, fax number +48 225534001 , telephone +48225534150
} 


\section{Contents}

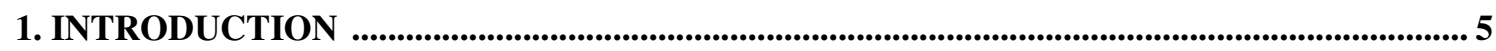

2.DYNAMIC RELATIONSHIP BETWEEN FINANCIAL INTERMEDIARY................5

2.1 The impact of hedge funds on market volatility..................................................5

2.2 Relationship between hedge funds and banks........................................6

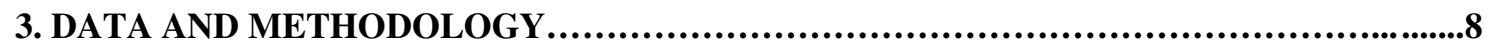

3.1 Correlation analysis..........................................................10

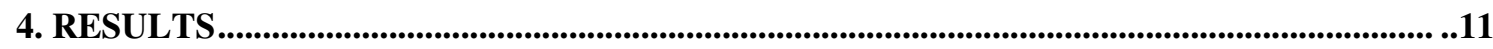

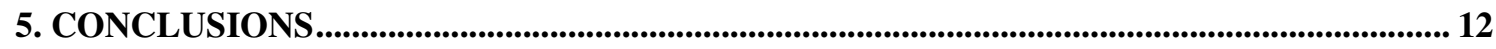

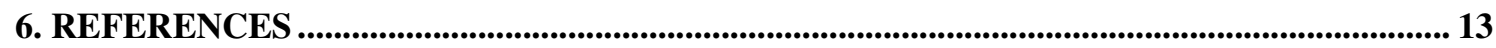




\section{INTRODUCTION}

The main feature of the classic investment intermediaries is that their rate of return depends on the volatility of price movement in financial markets. However, ones of them like hedge funds are trying to take advantage of the unusual size of investment strategies, so that the absolute achieved rate of return may occur during both bull and bear market. Therefore, their behavior is very high investment risk and investment strategies adopted are often aggressive and speculative (Karkowska, 2011, p.4). This hedge fund activities guarantees transactional liquidity, but also high volatility in the financial market, which may be the cause of excessive risk in the financial system. Available scientific studies emphasize that the financial intermediaries, particularly banks, significantly involved in the creation of various types of financial relationships with hedge funds (Billionaire, Getmansky, Lo, Pelizzon, 2010), (Fung, Hsieh, 2000), (ECB, 2009) (Eichengreen, 1998).

Over the time, this phenomenon has taken on a global character and contributed to the rise of the crisis. Unfortunately, when it comes to hedge funds, it can only be divided into groups of institutions that specialize in different types of investments, but it is hard to find on the ground, what is the scale of the risk taken by a specific group. This raises the question of the scale of the risks posed by hedge funds in the financial market?

The paper is organized as follows: Section 2 gives a brief overview about market volatility and financial intermmediary literature; Section 3 presents the using data and methodology; Section 4 provides results of regression model on volatility on selected capital markets and Section 5 provides conclusion.

\section{DYNAMIC RELATIONSHIP BETWEEN FINANCIAL INTERMEDIARY}

\subsection{THE IMPACT OF HEDGE FUNDS ON MARKET VOLATILITY}

The impact of hedge funds on market volatility can be analyzed in the following aspects (Fung, Hsieh, 2000, p.2):

$\checkmark$ Impact on prices/inadequacy of the valuation of assets, sale, when prices are falling/increased buying when asset prices are rising,

$\checkmark$ Strengthening market trend by hedge funds and/or entities cooperating with them, causing reactions gregarious (herding behavior),

$\checkmark$ Impact on increased volatility in asset prices, if a single fund or a group with a significant share of the market has similar investment strategies. Hedge fund strategies often rely on creating market imbalances and fluctuations in liquidity, 


\section{Faculty of Management Working Paper Series No 3/ 2013}

$\checkmark$ Impacts on above-average credit risk transfer entities, which can't effectively manage it. In order to increase the rate of return on hedge funds use high leverage of the instruments with built-in leverage and the so-called regulatory arbitrage by credit derivatives.

$\checkmark$ Lack of transparency in relationships with other financial institutions, resulting in failure to control the contagion effect systemic risk and contagion,

$\checkmark$ Dredging ties in trade, finance and equity between hedge funds and banks,

$\checkmark$ The lack of an effective and widely used methods of risk assessment and the hedge fund's ability to pay.

Hedge funds activities reveals several important factors affecting the growth of market volatility. One of the factors is leverage and leverage strategies, reflected in financing assets: loans, issuance of loans and debt securities. The amount and source of external financing hedge funds may have potential implications for financial stability risks, both through the credit channel and market. Most of the mechanisms of leverage employed by hedge funds include: borrowing money or increasing the exposure to the underlying assets by using leverage synthetic derivatives (Singh, 2012, p 14). These include: secured loan, taken out in the prime brokerage brokerage agreement, repurchase agreements (repos) and using synthetic instruments such as swaps (total return swap).

\subsection{RELATIONSHIP BETWEEN HEDGE FUNDS AND BANKS}

The last decade has also shown significantly increased financial intermediation of financial institutions, especially banks with hedge funds. This phenomenon is so dangerous that the instability in one institution entails a number of other capital associated with it, or transactionally. The recent crisis has shown that these relationships have taken on a global character and helped to generate risk (Cao, Chang, Wang, 2008).

The relationship between hedge funds and banks, which raise an additional platform to generate systemic risk are:

$\checkmark$ function that served as prime brokerage to hedge funds banks (this follows from the model that is practiced in the market). Bank may act as: 1/deliver of liquidity and financing is a short-term cash shortages associated with the mismatch between the terms of the fund's assets and liabilities may also be securities lending; settlement and custody, $2 /$ settlement center, $3 /$ technology center.

$\checkmark$ The bank's capital involvement on funds market, including the creation of hedge funds within the same group.

Recent studies also indicate that activity by hedge funds leads to an increased systemic risk (ECB, 2008). Systemic risk is also associated with a low degree of market transparency of hedge funds, the lack of reliable and publicly accessible information. As a result, funds may be used to prime brokerage 


\section{Faculty of Management Working Paper Series No 3/ 2013}

functions of several banking institutions at the same time, which undoubtedly enhances the risk for the entire financial system.

\section{Figure 1}

The European bank prime broker for hedge funds at the end of 2007 (\% of banks)

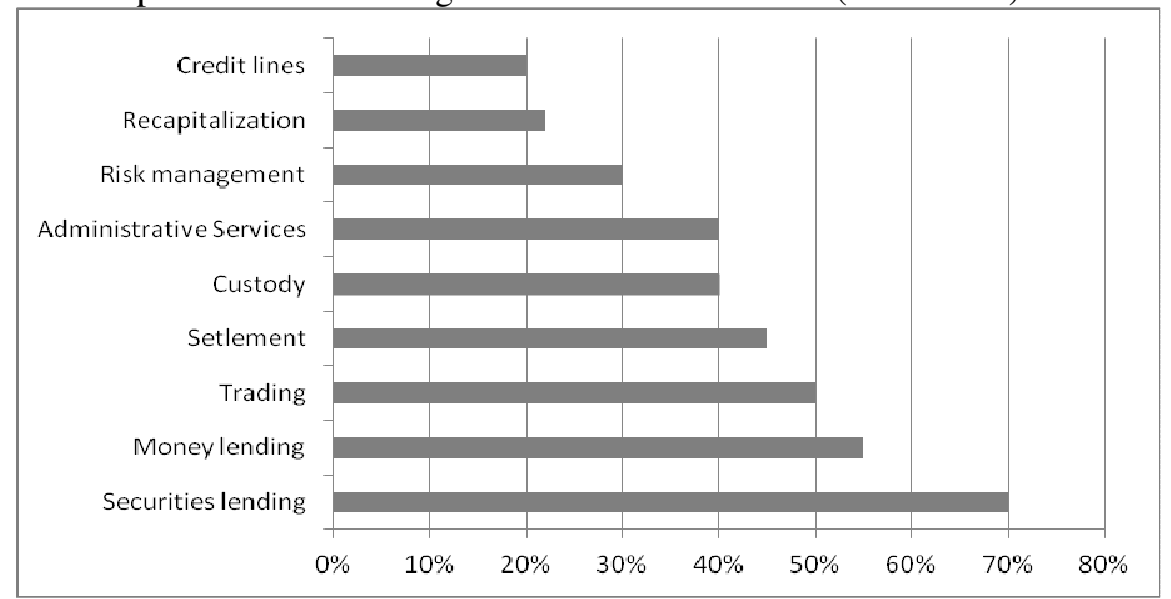

Source: (ECB, 2008)

The concentration of hedge funds on prime brokerage market is the highest in relation to finance and trading (see Figure 1). Billionaire, Getmansky, Lo, Pelizzon in 2010 conducted a study for the largest financial institutions in the world in the field of banking, insurance, hedge funds and financial brokers, designed to discover the degree of relationship between the interest groups. The study was conducted in five time trials: 1 / January 1994 - December 1996, 2 / January 1996 - December 1998, 3 / January 1999 - December 2001, 4 / January 2002 - December 2004, 5/ January 2006 - December 2008. In order to demonstrate the dynamics of relationships in the study used autocorrelation weighted assets, the normalized number of connections and the total number of links between all financial institutions. Test of Granger causality, which allows the statistical analysis of cause and effect relationships between variables, showed that the relationships among these financial institutions are very dynamic. The results are shown in Table 1. 


\section{Table 1}

Granger causality test of the relationship between monthly results the largest 25 banks, brokers, insurance companies and hedge funds in the five sample periods

\begin{tabular}{|c|c|c|c|c|c|c|c|c|c|}
\hline \multirow{2}{*}{ Sector } & \multirow{2}{*}{$\begin{array}{l}\text { Autocorrelation } \\
\text { Assets Weighted }\end{array}$} & \multicolumn{4}{|c|}{ Percentage of all possible links } & \multicolumn{4}{|c|}{ The total number of connections } \\
\hline & & $\begin{array}{l}\text { Hedge } \\
\text { funds }\end{array}$ & Brokers & Banks & Insurers & $\begin{array}{l}\text { Hedge } \\
\text { funds }\end{array}$ & Brokers & Banks & Insurers \\
\hline \multicolumn{10}{|c|}{ January 1994 - December 1996} \\
\hline All & $-0,07$ & $6 \%$ & & & & 583 & & & \\
\hline Hedge funds & 0,03 & $7 \%$ & $3 \%$ & $6 \%$ & $6 \%$ & 41 & 21 & 36 & 37 \\
\hline Brokers & $-0,15$ & $3 \%$ & $5 \%$ & $6 \%$ & $4 \%$ & 18 & 29 & 36 & 24 \\
\hline Banks & $-0,03$ & $6 \%$ & $7 \%$ & $9 \%$ & $7 \%$ & 40 & 46 & 54 & 44 \\
\hline Insurers & $-0,1$ & $5 \%$ & $6 \%$ & $6 \%$ & $9 \%$ & 33 & 38 & 35 & 51 \\
\hline \multicolumn{10}{|c|}{ January 1996 - December 1998} \\
\hline All & $-0,03$ & $9 \%$ & & & & 856 & & & \\
\hline Hedge funds & 0,08 & $14 \%$ & $6 \%$ & $5 \%$ & $3 \%$ & 82 & 38 & 30 & 20 \\
\hline Brokers & $-0,04$ & $13 \%$ & $9 \%$ & $9 \%$ & $9 \%$ & 81 & 53 & 54 & 57 \\
\hline Banks & $-0,09$ & $11 \%$ & $8 \%$ & $11 \%$ & $10 \%$ & 71 & 52 & 65 & 64 \\
\hline Insurers & 0,02 & $9 \%$ & $9 \%$ & $7 \%$ & $6 \%$ & 57 & 54 & 44 & 34 \\
\hline \multicolumn{10}{|c|}{ January 1999 - December 2001} \\
\hline All & $-0,09$ & $5 \%$ & & & & 520 & & & \\
\hline Hedge funds & 0,17 & $5 \%$ & $5 \%$ & $5 \%$ & $9 \%$ & 32 & 32 & 33 & 58 \\
\hline Brokers & 0,03 & $8 \%$ & $9 \%$ & $3 \%$ & $5 \%$ & 53 & 52 & 19 & 29 \\
\hline Banks & $-0,09$ & $5 \%$ & $3 \%$ & $4 \%$ & $7 \%$ & 30 & 17 & 25 & 42 \\
\hline Insurers & $-0,02$ & $5 \%$ & $3 \%$ & $2 \%$ & $6 \%$ & 32 & 16 & 14 & 36 \\
\hline \multicolumn{10}{|c|}{ January 2002 - December 2004} \\
\hline All & $-0,08$ & $6 \%$ & & & & 611 & & & \\
\hline Hedge funds & 0,20 & $10 \%$ & $3 \%$ & $9 \%$ & $5 \%$ & 61 & 20 & 56 & 29 \\
\hline Brokers & $-0,09$ & $8 \%$ & $4 \%$ & $4 \%$ & $6 \%$ & 53 & 23 & 26 & 39 \\
\hline Banks & $-0,14$ & $9 \%$ & $3 \%$ & $4 \%$ & $5 \%$ & 55 & 16 & 24 & 30 \\
\hline Insurers & 0,00 & $8 \%$ & $6 \%$ & $9 \%$ & $6 \%$ & 48 & 40 & 55 & 36 \\
\hline \multicolumn{10}{|c|}{ January 2006 - December 2008} \\
\hline All & 0,08 & $13 \%$ & & & & 1244 & & & \\
\hline Hedge funds & 0,23 & $10 \%$ & $13 \%$ & $5 \%$ & $13 \%$ & 57 & 82 & 31 & 83 \\
\hline Brokers & 0,23 & $12 \%$ & $17 \%$ & $9 \%$ & $12 \%$ & 78 & 102 & 55 & 73 \\
\hline Banks & 0,02 & $23 \%$ & $12 \%$ & $10 \%$ & $9 \%$ & 142 & 74 & 58 & 54 \\
\hline Insurers & 0,12 & $13 \%$ & $16 \%$ & $12 \%$ & $16 \%$ & 84 & 102 & 73 & 96 \\
\hline
\end{tabular}

Source: (Billio, Getmansky, Lo, Pelizzon, 2010, p. 26)

For example, at the beginning of the trial (1994-1996) the total number of linkages between financial institutions was 583, but ten years later (2006-2008) more than doubled to 1244 . Also demonstrated that during and before the financial crisis the financial system becomes more connected with each other compared to the more peaceful periods (as confirmed by the time LTCM crisis of 1998 and the recent financial crisis 2007-2009). In a relatively quiet period 1994-1996, the total number of links, calculated as a percentage of all possible links was $6 \%$, and the total number of calls of financial institutions - 583. Just before and during the LTCM crisis (1996-1998), the number of 


\section{Faculty of Management Working Paper Series No 3/ 2013}

connections increased by $50 \%$ to 856 including $9 \%$ of all possible links. Both the LTCM crisis of 1998 and the financial crisis from 2007 to 2009 were associated with problems of liquidity and credit. During this period, hedge funds have significant bilateral relationships with insurers and brokers, but most of the activities of banks (23\% of all possible links). From the point of view of the cause of market return volatility increasing number of links is undoubtedly a significant factor contributing to the instability of the system.

The risk of "contagion effect " and the insolvency of the institutions directly or indirectly associated with hedge funds is the result of the mechanisms that are practiced in the market. These can include:

$\checkmark$ strategies imitation used by hedge funds that exists between these institutions, despite the fact that usually emphasized their independence from the trend of market,

$\checkmark$ replicated by other financial institutions, mainly banks, a strategy used by hedge funds,

$\checkmark$ frequent and unexpected change strategies used by funds or involvement in the market, which is a particularly dangerous to the financing banks.

To read the impact of hedge funds on the risk of price volatility in the financial markets (stocks, bonds, CDS) was carried out the following analysis.

\section{DATA AND METHODOLOGY}

Benchmark used to reflect the volatility of returns on the various markets served: S\&P500 index for equities, iBoxx Index for bonds and CDS index spreads for credit default swaps (data source is Eikon Thomson Reuters). Due to data availability study was limited to the period 2001-2011. Data on hedge fund reporting is taken from the FSA's Hedge Fund Survey. The study used three multiple regression models. The first one estimates the impact of market development (measured by the amount of assets), leverage used and the involvement of hedge funds on the volatility of returns on the stock market (EQ) (1), the bonds in the second model (EQ (2)) and CDS credit spread in the model third (EQ (3)). Models are expressed using the following equations:

Vol_inx_eq ${ }_{t}=\alpha_{0}+\alpha_{1}$ Lev_equity $t+\alpha_{2}$ Lev_cds $_{t}+\alpha_{3}$ Lev_bond ${ }_{t}+\alpha_{4}$ Hedge_market $t_{t}+\alpha_{5}$ Equity_share $_{t}$ $+\alpha_{6} C D S \_$share ${ }_{t}+\alpha_{7}$ Bond_share $_{t}+\alpha_{8}$ Vol_inx_bond $d_{t-1}+\alpha_{9}$ Vol_cds $t_{t-1}+\varepsilon_{t}$

Vol_inx_bond $_{t}=\beta_{0}+\beta_{1}$ Lev_equity $_{t}+\beta_{2}$ Lev_cds $_{t}+\beta_{3}$ Lev_bond $_{t}+\beta_{4}$ Hedge_market ${ }_{t}+$ $\beta_{5}$ Equity_share $_{t}+\beta_{6} C D S \_$share $_{t}+\beta_{7}$ Bond_share $_{t}+\beta_{8} V o l \_i n x \_e q_{t-1}+\beta_{9} V o l \_c d s_{t-1}+\varepsilon_{t}$

$(\mathrm{EQ}(2))$ 


\section{Faculty of Management Working Paper Series No 3/ 2013}

$V_{0} \_c d s_{t}=\lambda_{0}+\lambda_{1}$ Lev_equity $_{t}+\lambda_{2}$ Lev_cds $_{t}+\lambda_{3}$ Lev_bond $_{t}+\lambda_{4}$ Hedge_market $t_{t}+\lambda_{5}$ Equity_share $_{t}+$ $\lambda_{6} C D S \_$share $_{t}+\lambda_{7}$ Bond_share $_{t}+\lambda_{8}$ Vol_inx_bond ${ }_{t-1}+\lambda_{9} V o l \_i n x \_e q_{t-1}+\varepsilon_{t}$

where:

index $t$ refers to time, changes are annual; Lev_equity $_{t}$ - logarithm of the leverage ratio, which is used by the funds in the stock market, $L e v \_c d s_{t}$ - logarithm of the leverage ratio, which is used by the funds

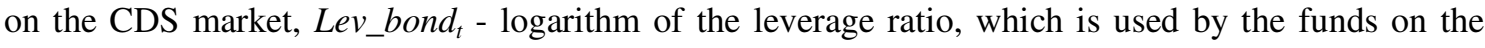
bond market, Hedge_market $t_{t}$ - change the size of hedge fund assets, Equity_share ${ }_{t}$ - participation of hedge funds in the stock market, CDS_share $t_{-}$- hedge funds as the part of the CDS market, Bond_share $_{t}$ - the share of hedge funds on the bond market, Vol_cds $s_{t}$ - the volatility of the CDS market, Vol_inx_eq $q_{t}$ - volatility equity index, Vol_inx_bond $t_{t}$ - bond index volatility, $\varepsilon_{t^{-}}$error measurement (white noise).

To the equation (EQ (1)), which tests volatility, added spread variability on the CDS market and the bond index in order to determine whether the variability of the other markets affects the market and the size of these variables are interrelated. Adequately to the above principle was also applied in the equation (EQ (2)) and (EQ (3)).

Estimation of parameter model were carried out using the method GLS method (Generalized Least Squares), used in the analysis of time series models in the financial market. Significance testing was carried out and the analysis of parameters of the model goodness of fit parameters. Calculations were performed in the STATA statistical program.

\subsection{CORRELATION STUDY}

Preliminary examination of the variables showed a positive correlation and statistically significant relationship between price volatility in the bond market and CDS, which may suggest that an increase in the risk of volatility in the bond market coincides with an increased risk of the CDS market, and vice versa. This is due to the nature of the links which are present in both types of transactions belonging to the debt market. CDS are derivatives transactions in bonds and hedge credit

risk generated by them. However, a negative correlation between the risk of the stock market and bond/CDS suggests that the increase in volatility in one market is associated with a decrease in volatility in the second. This reasoning confirms the trend movement of investment capital between markets and less risky.

The vast majority of the independent variables used in the model are significantly correlated with the dependent variables. The results of the analysis of a linear relationship between the variables applied in the study are presented in Table 2 . 


\title{
Faculty of Management Working Paper Series No 3/ 2013
}

Table 2

Linear correlation coefficients of variables used in the study for the observation of the sample 20012011

\begin{tabular}{|c|c|c|c|c|c|c|c|c|c|c|}
\hline $\begin{array}{l}\text { Lev_equi } \\
\text { ty }\end{array}$ & $\begin{array}{l}\text { Lev_c } \\
\text { ds }\end{array}$ & $\begin{array}{l}\text { Lev_bon } \\
\text { d }\end{array}$ & $\begin{array}{l}\text { Hedge_m } \\
\text { arket }\end{array}$ & $\begin{array}{l}\begin{array}{l}\text { Equity_sha } \\
\text { re }\end{array} \\
\end{array}$ & $\begin{array}{l}\text { CDS_sha } \\
\text { re }\end{array}$ & $\begin{array}{l}\text { Bond_sha } \\
\text { re }\end{array}$ & $\begin{array}{l}\text { Vol_c } \\
\text { ds }\end{array}$ & $\begin{array}{l}\text { Vol_inx } \\
\text { eq }\end{array}$ & $\begin{array}{l}\text { Vol_inx_bo } \\
\text { nd }\end{array}$ & \\
\hline 1,00 & $\begin{array}{l}0,63 \\
1,00\end{array}$ & $\begin{array}{l}0,833 \\
0,751 \\
1,000\end{array}$ & $\begin{array}{l}0,3900 \\
0,2894 \\
0,2983 \\
1,00\end{array}$ & $\begin{array}{l}0,9087 \\
0,8315 \\
0,8788 \\
0,3072 \\
1,00\end{array}$ & $\begin{array}{l}-0,397 \\
-0,576 \\
-0,505 \\
-0,206 \\
-0,543 \\
1,00\end{array}$ & $\begin{array}{l}0,7987 \\
0,6611 \\
0,9049 \\
0,4034 \\
0,8219 \\
-0,411 \\
1,00\end{array}$ & $\begin{array}{l}0,62 \\
0,20 \\
0,57 \\
-0,41 \\
0,57 \\
0,11 \\
0,52 \\
1,00\end{array}$ & $\begin{array}{l}-0,1903 \\
-0,0434 \\
-0,1135 \\
0,4411 \\
0,2984 \\
-0,1060 \\
-0,2615 \\
-0,6647 \\
1,0000\end{array}$ & $\begin{array}{l}-0,2581 \\
-0,2475 \\
-0,4045 \\
-0,5023 \\
-0,2300 \\
0,5519 \\
0,2595 \\
0,3011 \\
-0,7179 \\
1,0000\end{array}$ & $\begin{array}{l}\text { Lev_equity } \\
\text { Lev_cds } \\
\text { Lev_bond } \\
\text { Hedge_market } \\
\text { Equity_share } \\
\text { CDS_share } \\
\text { Bond_share } \\
\text { Vol_cds } \\
\text { Vol_inx_eq } \\
\text { Vol inx bond }\end{array}$ \\
\hline
\end{tabular}

Sources: own calculation

\begin{abstract}
Notes: The critical value at the level of the two-sided $5 \%=0.1132$, Explanation: Lev_equity - logarithm of leverage in the stock market, Lev_cds - log of leverage on the CDS market, Lev_bond - log leverage ratio on the bond market, Hedge_market - changes in hedge fund assets, Equity_share - participation of hedge funds in the stock market, CDS_share - the share of funds hedge the CDS market, Bond_share participation of hedge funds in the bond market, Vol_cds - the volatility of the CDS market, Vol_inx_eq - equity index volatility, Vol_inx_bond - bond index volatility.
\end{abstract}

\section{RESULTS}

Analysis of the significance of the involved variables and the level of parameters provided findings, confirming the hypothesis previously wagered, the significant effect of hedge funds at rising market return volatility in the financial system. The results presented in Table 3 indicate that the volatility of stock prices seems to be the greatest level dictated by leverage used by hedge funds (27.73), in a much less affected by the leverage used by the CDS market funds and bonds (3.43, 3.02). Model also confirms the earlier correlation study between the share of hedge funds in the stock market and the volatility of stock market index S\&P500 (the share will rise to the level of variation (106.47). Relationship between the volatility of market bonds and CDS prices and equity index volatility is asymmetric, which suggests the possibility of speculative capital movements between different markets.

The study showed that in the period 2001-2011 bond's volatility was positively correlated with the level of leverage used by hedge funds in the stocks, bonds and CDS markets. The explanation for this phenomenon is commonly used by funding strategies for bonds convertible into shares and the transfer of credit risk in the CDS market. The increase in the funds share in the bond market significantly and positively affect the volatility of bond prices and contrary the increase of funds in the stock market reduces this variability. A similar negative correlation effects accompanied by volatility of the volatility of bond prices. The study of variation CDS credit spread levels showed a statistically significant and positive correlation with the level of leverage used by the fund (108.58), and the share of the debt market (bonds and CDS). This relationship is negative, when rising the share of funds in the stock market (-416.3). 


\section{Faculty of Management Working Paper Series No 3/ 2013}

\section{Table 3}

The results of the study on the impact of hedge funds the level of market return volatility in the financial system

\begin{tabular}{|c|c|c|c|c|c|c|c|c|c|}
\hline $\begin{array}{l}\text { Dependent } \\
\text { variable }\end{array}$ & $\begin{array}{l}\text { Equity } \\
\text { volatility }\end{array}$ & return & & $\begin{array}{l}\text { Bonds } \\
\text { volatility }\end{array}$ & return & & $\begin{array}{l}\text { CDS } \\
\text { volatility }\end{array}$ & spread & \\
\hline & Indicator & $p$-value & & Indicator & $p$-value & & Indicator & $p$-value & \\
\hline Const & 0,0278 & 0,2751 & & 0,01212 & 0,25159 & & 0,107196 & 0,29844 & \\
\hline Lev_equity & 27,739 & 0,0197 & $* *$ & 11,8723 & 0,04149 & $* *$ & 108,583 & 0,03827 & $* *$ \\
\hline Lev_cds & 3,436 & 0,0579 & $*$ & 1,47649 & 0,04023 & $* *$ & 13,404 & 0,08575 & $*$ \\
\hline Lev_bond & 3,023 & 0,0268 & $* *$ & 1,29112 & 0,06264 & $*$ & 11,8573 & 0,01809 & $* *$ \\
\hline Hedge_market & 0,039 & 0,0255 & $* *$ & 0,01705 & 0,05442 & $*$ & 0,156198 & 0,03891 & ** \\
\hline Equity_share & 106,476 & 0,0210 & $* *$ & $-45,5968$ & 0,03625 & $* *$ & $-416,43$ & 0,04703 & $* *$ \\
\hline CDS_share & 1,501 & 0,0341 & $* *$ & 0,64258 & 0,05074 & $*$ & 5,88506 & 0,03482 & $* *$ \\
\hline Bond_share & $-17,368$ & 0,0180 & $* *$ & 7,42354 & 0,05243 & $*$ & 68,0541 & 0,02444 & $* *$ \\
\hline Vol_inx_eq & & & & $-0,42794$ & 0,03774 & $* *$ & $-3,91489$ & 0,0311 & $* *$ \\
\hline Vol_inx_bond & $-2,328$ & 0,0377 & $* *$ & & & & 9,09533 & 0,06505 & $*$ \\
\hline Vol_CDS & $-0,254$ & 0,0311 & $* *$ & 0,10880 & 0,06505 & $*$ & & & \\
\hline $\mathrm{R}^{2}=$ & 0,99995 & & & 0,99963 & & & 0,999864 & & \\
\hline $\begin{array}{l}\text { Residual Standard } \\
\text { Error }=\end{array}$ & 0,00462 & & & 0,00198 & & & 0,018125 & & \\
\hline Test $\mathrm{F}=$ & 657,093 & & & 304,416 & & & 814,0055 & & \\
\hline $\mathrm{p}$-value for $\mathrm{F}$ test $=$ & 0,01505 & & & 0,04445 & & & 0,027195 & & \\
\hline
\end{tabular}

Source: own study

Notes: const - constant variable, Lev_equity - logarithm of leverage in the stock market, Lev_cds - logarithm of leverage on the CDS market, Lev_bond - log leverage ratio on the bond market, Hedge_market - changes in hedge fund assets, Equity_share - participation of hedge funds in the stock market CDS_share - the share of hedge funds on the CDS market, Bond_share - the share of hedge funds on the bond market, Vol_cds - the volatility of the CDS market, Vol_inx_eq - equity index volatility, Vol_inx_bond - bond index volatility.

*, **, *** - determination of statistical significance as appropriate for the $10 \%, 5 \%, 1 \%$. Test $\mathrm{F}$ - examines the total significance of the explanatory variables, the level indicates a rejection of the null hypothesis in favor of the alternative hypothesis.

\section{CONCLUSION}

Due to the lack of restrictions on investment policy, the orientation of the absolute rate of return and the constant search for anomalies in the valuation of financial instruments for profit, have contributed to the fact that hedge funds have become one of the most important financial institutions. On the other hand, the demand for credit risk, effective diversification of the investment portfolio and the relatively high volatility of credit spreads, led to also become a major player in the credit derivatives market and the values issued in the securitization process. Their activity, associated with the use of high leverage and the dynamics of the strategy adopted, causes significant volatility in the markets. The analysis of the potential impact on market volatility confirms it and puts hedge funds in the less stable position in the financial system. 


\section{Faculty of Management Working Paper Series No 3/ 2013}

\section{REFERENCE}

Billio M., Getmansky M., Lo A. W., Pelizzon L. (2010), Econometric measures of systemic risk in the finance and insurance sectors, NBER Working Paper, No 16223, July.

Cao Ch., Chang E. C., Wang Y. (2008). An empirical analysis of the dynamic relationship between mutual fund flow and market return volatility, Journal of Banking \& Finance, Volume 32, Issue 10, October, Pages 2111-2123.

Eichengreen B., Matchieson D., Chandha B., Jensen A., Kodres L., Sharma S. (1998), Hedge funds and financial markets dynamic, IMF Occasional Paper, No 166, May.

European Central Bank (ECB), (2008), Large EU banks' exposures to hedge funds, November.

Fung W., Hsieh D. A., (2000), Measuring the market impact of hedge funds, Journal of Empirical Finance, No 7.

Karkowska R. (2011), Hedge funds - identification of risk and investment opportunities. Economy, society and managing, p. 200-213, WZ UW.

Kot S., Jakubowski J., Sokołowski A., (2011), Statistica, Difin, Warsaw.

Financial Services Authority: Assessing the possible sources of systemic risk from hedge funds, A report on the findings of the FSA's Hedge Fund Survey and Hedge Fund as Counterparty Survey, February, 2012.

Singh M., (2012), The (Other) Deleveraging, IMF Working Paper, July. 